\title{
Activation peptide of carboxypeptidase B in serum and urine in acute pancreatitis
}

\author{
S Appelros, L Thim, A Borgström
}

\begin{abstract}
Background-The pathophysiology of acute pancreatitis involves activation of the pancreatic proenzymes. Levels of the trypsinogen activation peptide in urine in acute pancreatitis has been shown to correlate with the severity of disease. However, this peptide is unstable in urine and, because of its low molecular mass, difficult to measure. Procarboxypeptidase B has a larger activation peptide which could be more suitable for analysis in serum and urine.
\end{abstract}

Aims-To study the presence of the activation peptide from procarboxypeptidase $B$ (CAPAP) in serum and urine in acute pancreatitis.

Patients-Urine and serum samples were obtained within 48 hours of admittance from 40 patients with acute pancreatitis. Severity was classified retrospectively according to levels of $\mathrm{C}$-reactive protein and clinical course. Thirty four patients with abdominal pain from other causes were studied as controls.

Methods-CAPAP was purified from human pancreatic juice. Specific antibodies were obtained and a radioimmunoassay was developed.

Results-Levels of CAPAP in serum and urine in acute pancreatitis correlate with the severity of the attack. CAPAP is very stable, and urine contains only CAPAP whereas, in serum, cross reacting procarboxypeptidase $B$ is found together with CAPAP.

Conclusions-CAPAP could be a valuable tool in the diagnosis and early determination of severity in acute pancreatitis. (Gut 1998;42:97-102)

Departments of Surgery and Surgical Pathophysiology, University Hospitals in Malmö, University of Lund, Sweden S Appelros

A Borgström

Department of Protein Chemistry, Novo

Nordisk Als, DK-2880

Bagsvaerd, Denmark

L Thim

Correspondence to:

Dr A Borgström Department

of Surgery, University

Hospitals in Malmö, S-205

02 Malmö, Sweden.

Accepted for publication 15 July 1997 complement factors occurs, resulting in a massive inflammatory reaction and an accumulation of inflammatory cells. Trypsin also activates other pancreatic proenzymes such as prophospholipase $^{2}$ and proelastase ${ }^{3}$ and, to- gether with the release of granulocyte proteases, adds to the tissue destruction. Many of the pancreatic proenzymes release an activation peptide during the trypsin-induced activation including trypsinogen itself. Most of these peptides are small $(<1 \mathrm{kDa})$ and rapidly excreted in the urine. Procarboxypeptidase B (proCPB) differs from most of the pancreatic proenzymes by its large $(10 \mathrm{kDa})$ activation peptide. ${ }^{4}$ The purpose of this study was to purify and characterise the activation peptide from human carboxypeptidase B (CAPAP). We also developed a sensitive radioimmunoassay for this peptide. Further we wanted to measure and characterise the "CAPAP-like immunoreactivity" detected when using this assay in serum and urine during acute pancreatitis in man.

\section{Materials and methods}

PURIFICATION OF CAPAP

Pancreatic juice was collected from patients who had had their main pancreatic duct drained after major pancreatic surgery. The juice was collected in a plastic bag without additives and for practical purposes was initially left at room temperature for up to eight hours before being frozen and stored at $-20^{\circ} \mathrm{C}$ for up to six months. A $20 \mathrm{ml}$ sample of the juice was applied to a column of aprotinin coupled to Sepharose for the neutralisation of trypsin and trypsinogen as described previously. ${ }^{6}$ The effluent from this column contained all pancreatic proenzymes except trypsinogen. The fractions were analysed for proCPB activity, after activation with trypsin, using hippuryl-L-arginine (Sigma Chemical Company, St Louis, Missouri, USA), ${ }^{7}$ and the proteins were visualised by agarose gel electrophoreses at $\mathrm{pH} 8.6$ as described by Johansson. ${ }^{8}$ The fractions containing proCPB were transferred to a Tris/ $\mathrm{HCl}$ buffer $0.02 \mathrm{~mol} / \mathrm{l}$ at $\mathrm{pH} 7.5$ using a PD-10 column (Pharmacia, Uppsala, Sweden) and then applied to a Mono $Q$ column (HR 5/5; Pharmacia Biotech) using an FPLC system (LKB Pharmacia). The column was equilibrated with the $\mathrm{Tris} / \mathrm{HCl}$ buffer mentioned above and eluted with a linear gradient with $\mathrm{NaCl}$ from 0 to $0.35 \mathrm{~mol} / 1$ at 1 $\mathrm{ml} / \mathrm{min}$. Fractions of $0.5 \mathrm{ml}$ were collected and analysed for proCPB as described above. Agarose gel electrophoresis showed a single slightly anionic protein band (fig 1). The fractions containing pure proCPB were transferred to a Tris/ $\mathrm{HCl}$ buffer $0.02 \mathrm{~mol} / 1$ at $\mathrm{pH} 8.2$ using a PD-10 column as previously mentioned followed by trypsin activation (bovine pancreas type 1 ; Sigma). Activation was induced by incubation with trypsin $(0.01 \mathrm{mg} / \mathrm{ml})$ at room 


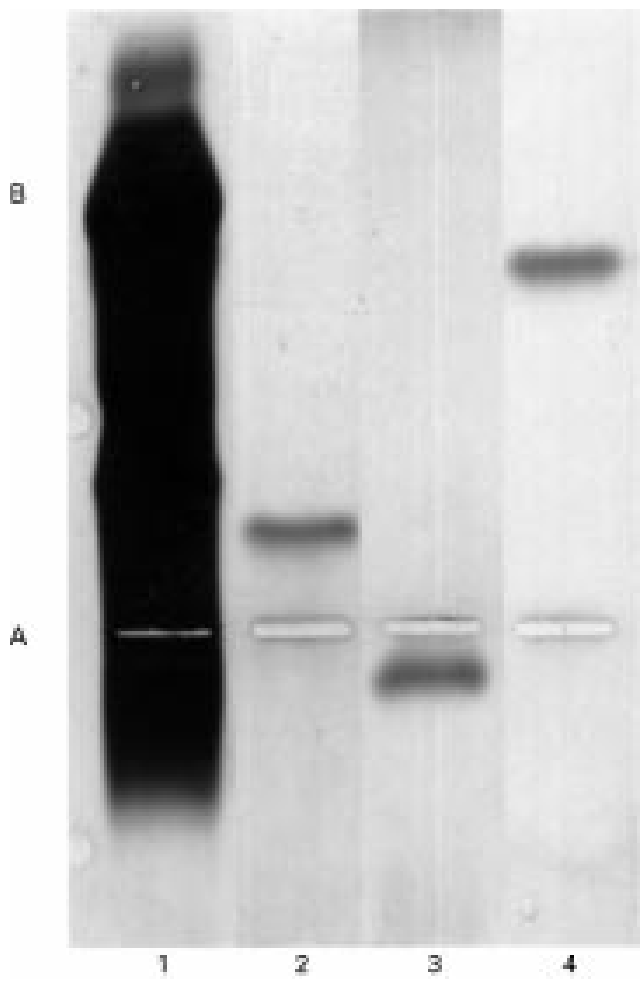

Figure 1 Agarose gel electrophoresis at pH 8.6 of pure procarboxypeptidase $B$ (lane 2), pure active carboxypeptidase B (lane 3) and pure carboxypeptidase $B$ activation peptide (lane 4). The electrophoretic pattern of human serum is shown as a reference in lane 1. A indicates the application slit and $B$ the albumin band in serum.

temperature for 60 minutes. Then $3.5 \mathrm{ml}$ of the activated pure proCPB (about $2-3 \mathrm{mg}$ ) was applied to the Mono $\mathrm{Q}$ column mentioned above and eluted with a linear gradient with $\mathrm{NaCl}$ from 0 to $0.35 \mathrm{~mol} / 1$ at $1 \mathrm{ml} / \mathrm{min}$. The fractions containing the activation peptide (CAPAP) were further purified on a Sephadex G-50 column $(1.0 \mathrm{~cm} \times 60 \mathrm{~cm})$ in Tris $/ \mathrm{HCl}$ buffer $0.05 \mathrm{~mol} / 1$ containing $\mathrm{CaCl}_{2} 0.05 \mathrm{~mol} / 1$ at $\mathrm{pH}$ 7.4. The purified CAPAP was concentrated by ultrafiltration for 60 minutes at $4^{\circ} \mathrm{C}$ on a Centricon-3 filter (Amicon Inc, Beverly, Massachusetts, USA). The final concentration of CAPAP was determined by the method of Lowry et al ${ }^{9}$ using bovine serum albumin (BSA; Sigma) as the standard.

$\mathrm{N}$-Terminal amino acid sequences were determined by automated Edman degradation using an Applied Biosystems 494 protein sequencer. ${ }^{10}$

Mass spectroscopic analysis was performed using an API III LC/MS/MS system (Sciex, Thornhill, Ontario, Canada). ${ }^{11}$ Before injection, the sample was passed over a Vydac $214 \mathrm{TP} 54$ reversed-phase $\mathrm{C}_{4}$ high performance liquid chromatography column $(4.6 \mathrm{~mm} \times 260$ $\mathrm{mm}$ ) equilibrated at a flow rate of $1 \mathrm{ml} / \mathrm{min}$ with $0.1 \%(\mathrm{v} / \mathrm{v})$ trifluoroacetic acid. The column was eluted by increasing the concentration of acetonitrile from 0 to $100 \%$ in the eluting solvent.

ANTISERA

Rabbits were immunised with intracutaneous injections of $0.1 \mathrm{mg}$ pure CAPAP and Freund's complete adjuvant (Difco Laboratories, De- troit, Michigan, USA). Every third week the rabbits were given a booster injection of $0.1 \mathrm{mg}$ pure CAPAP and Freund's incomplete adjuvant. The presence of antibodies was tested by immunoelectrophoresis against pancreatic juice before and after activation and against the purified CAPAP. The antiserum from the bestresponding animal was used.

RADIOLABELLING OF CAPAP

CAPAP was labelled with ${ }^{125} \mathrm{I}$ using the BoltonHunter method. ${ }^{12}$ After labelling, free and protein bound ${ }^{125} \mathrm{I}$ were separated on a PD-10 column and in a second step on a Sephadex G-50 column $(1.6 \mathrm{~cm} \times 36 \mathrm{~cm})$ using Tris $/ \mathrm{HCl}$ buffer $0.02 \mathrm{~mol} / 1$ containing $0.1 \% \quad(\mathrm{w} / \mathrm{v})$ gelatine at $\mathrm{pH} 7.5$.

The radiolabelled protein was characterised using agarose gel electrophoresis. After electrophoresis, the gel was cut into $5 \mathrm{~mm}$ broad strips parallel to the application slit. The radioactivity of each strip was measured, and the electrophoretic mobility of the labelled protein was determined and compared with the mobility of pure CAPAP. The radiolabelled protein was also characterised by gel filtration on the Sephadex G-50 column mentioned above.

\section{RADIOIMMUNOASSAY}

All dilutions were made with a $0.05 \mathrm{~mol} / 1$ Tris/ $\mathrm{HCl}$ buffer containing $0.05 \mathrm{~mol} / 1 \mathrm{CaCl}_{2}, 0.02 \%$ $(\mathrm{w} / \mathrm{v})$ sodium azide and $0.2 \%(\mathrm{w} / \mathrm{v}) \mathrm{BSA}$, at $\mathrm{pH}$ 7.4. Pure CAPAP was used as the standard in dilutions from 0.14 to $70 \mathrm{nmol} / 1$. The antibody was used at a dilution of 1:8000. The samples, tracer, and antibody were incubated overnight at $+4^{\circ} \mathrm{C}$. Free and bound radioactivity were separated by means of a second antibody precipitation step using Pharmacia decanting suspension (sheep anti-rabbit antibody) (Pharmacia AB). After four hours of incubation, the sample was centrifuged at $2500 \mathrm{~g}$ for 15 minutes, and the supernatant was isolated. The radioactivity of the precipitate was counted in a $\gamma$ spectrometer with scintillation detectors.

The cross reaction with proCPB was tested by measuring the CAPAP-like immunoreactivity of pure proCPB before and after activation with trypsin as described above.

CHARACTERISATION OF IMMUNOREACTIVE (IR) CAPAP IN SERUM AND URINE

For characterisation of the measured CAPAPlike immunoreactivity in serum and urine, the samples were subjected to gel filtration on a Sephadex G-50 column $(1.6 \mathrm{~cm} \times 36 \mathrm{~cm})$ using a $0.05 \mathrm{~mol} / 1 \mathrm{Tris} / \mathrm{HCl}$ buffer with 0.05 $\mathrm{mol} / 1 \mathrm{CaCl}_{2}, 0.02 \%(\mathrm{w} / \mathrm{v})$ sodium azide, and $0.2 \%(\mathrm{w} / \mathrm{v}) \mathrm{BSA}$, at $\mathrm{pH} 7.4$. Fractions of $0.5 \mathrm{ml}$ were analysed for irCAPAP.

In addition, the immunoreactive material in urine was characterised using preparative agarose gel electrophoresis. ${ }^{8}$ After electrophoresis of urine from patients, the gel was cut into 5 $\mathrm{mm}$ broad strips parallel to the application slit. The different strips were frozen at $-20^{\circ} \mathrm{C}$, thawed, and the supernatant from each strip was analysed for irCAPAP. A similar electrophoretic procedure was carried out for purified CAPAP for comparison. 
Table 1 Diagnosis in cases with acute abdominal pain other than acute pancreatitis

\begin{tabular}{lc}
\hline Diagnosis & Number of patients \\
\hline Abdominal pain/non-ulcer dyspepsia & 10 \\
Appendicitis & 6 \\
Ileus & 4 \\
Biliary disorders & 3 \\
Gastroenteritis & 3 \\
Duodenal ulcer & 1 \\
Ventricular ulcer & 1 \\
Malignant lymphoma & 1 \\
Sigmoid cancer & 1 \\
Pyelonephritis & 1 \\
Sigmoiditis & 1 \\
Tubo-ovarial abscess & 1 \\
Gastritis & 1 \\
Total & 34 \\
\hline
\end{tabular}

STABILITY OF irCAPAP IN SERUM AND URINE To test the stability of irCAPAP, urine and serum samples were kept in the refrigerator at $+4^{\circ} \mathrm{C}$ for 4 weeks and analysed each week.

PATIENT MATERIAL

Forty patients admitted to the emergency room with the clinical diagnosis of acute pancreatitis

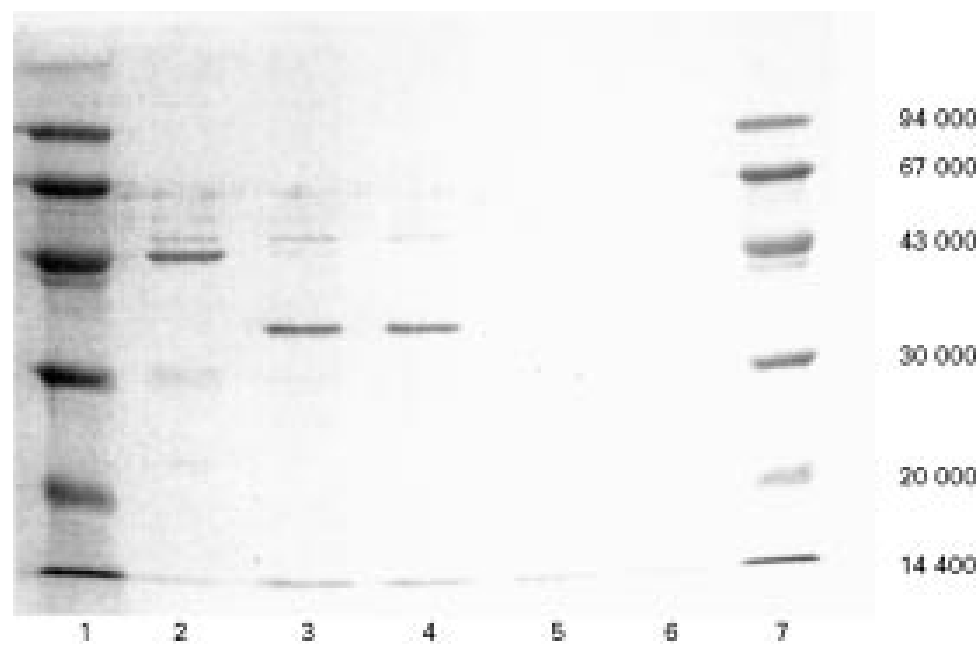

Figure 2 Sodium dodecyl sulphate/polyacrylamide gel electrophoresis (12\% gel) of procarboxypeptidase $B$ (proCPB) before activation (lane 2), active CPB together with the activation peptide (CAPAP) (after activation of proCPB with trypsin) (lanes 3 and 4), and purified CAPAP (lanes 5 and 6). Molecular mass standards are shown in lanes 1 and 7.

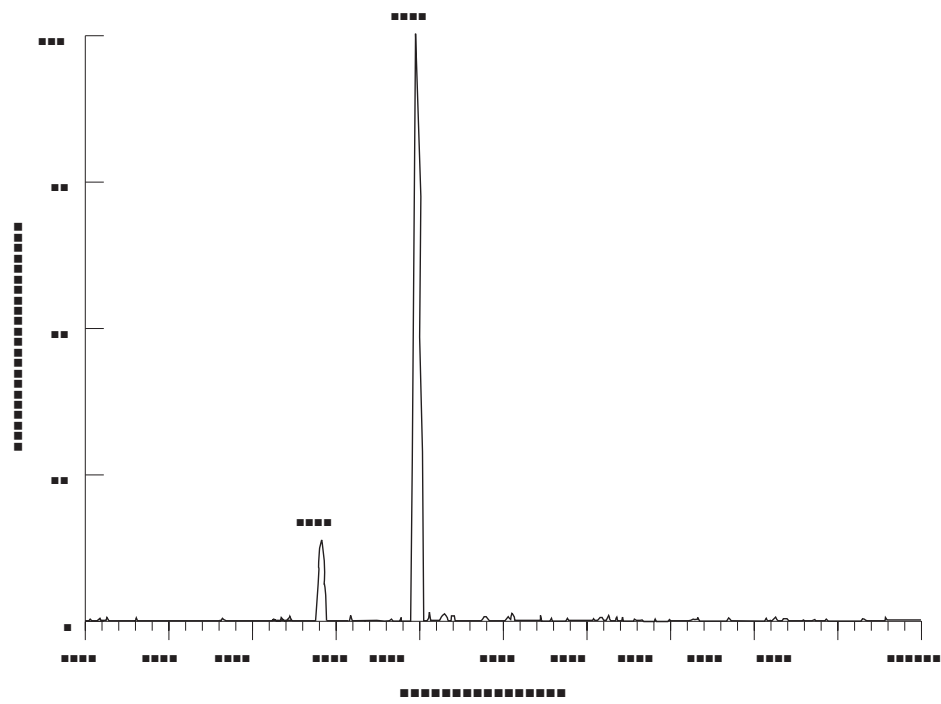

Figure 3 Electrospray mass spectroscopic analysis of the purified activation peptide. (acute abdominal pain with elevated serum amylase activity) were included. Patients were included if the history of disease at admittance was three or fewer days and if serum and urine samples were obtained within 48 hours of admission. The severity of the attack was classified retrospectively as mild if the peak value of C-reactive protein was less than 100 (19 patients) and as moderate if the peak C-reactive protein was 100 or higher (17 patients). The attack was considered severe if the patient developed organ failure or severe local complications needing treatment in the intensive care unit (four patients). The median age of the patients was 63 years (range 25-90 years). Twenty patients were men. The aetiology of the pancreatitis was biliary in 17 , alcohol in 13, endoscopic retrograde cholangiopancreatography in five, and unknown in five. Serum and urine samples were also collected from 34 patients with acute abdominal pain from causes other than acute pancreatitis and analysed (table 1). We also analysed serum and urine samples from five patients with recently diagnosed pancreatic cancer.

STATISTICAL ANALYSIS

The Mann-Whitney U test (non-parametric test) was used to compare groups. Differences were considered significant when $\mathrm{p}<0.05$. Macintosh Statview 4.5 was used for the calculation.

\section{Results}

PURIFICATION OF CAPAP

CAPAP was obtained as a single anionic band on agarose gel electrophoresis (fig 1). On sodium dodecyl sulphate/polyacrylamide gel electrophoresis, only one band migrating with the front was seen corresponding to a peptide with a molecular mass of less than $14 \mathrm{kDa}$ (fig 2).

STRUCTURE OF CAPAP

The N-terminal sequence analysis showed the following residues: His-His-Gly-Gly-Glu-HisPhe-Glu-Gly-Glu. Mass spectroscopic analysis showed one peak corresponding to a molecular mass of $9398 \pm 5 \mathrm{Da}$ (fig 3).

ANTISERA

Immunoelectrophoresis against pancreatic juice showed one faint precipitate close to the application site corresponding to the migration of proCPB. After activation, a highly anionic precipitate appeared, corresponding to the mobility of the purified CAPAP. There was no cross reaction with active $\mathrm{CPB}$.

RADIOLABELLING OF CAPAP

CAPAP showed the same electrophoretic mobility on agarose gel electrophoresis and the same molecular mass on gel filtration on the Sephadex G-50 column after labelling as the native protein. The antibody used in the radioimmunoassay was able to precipitate $94 \%$ of the labelled CAPAP when used in excess.

RADIOIMMUNOASSAY FOR IRCAPAP

Figure 4 shows a dilution curve of the pure CAPAP used as the standard together with 


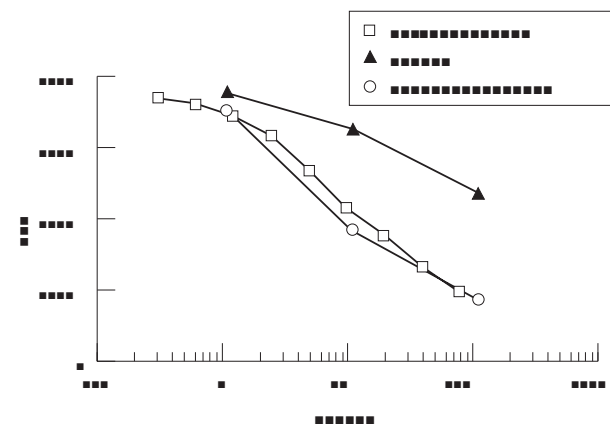

Figure 4 Assay for immunoreactive carboxypeptidase B activation peptide (CAPAP). Dilution curve for pure CAPAP (CAPAP standard), together with dilution curves for procarboxypeptidase $B$ (proCPB) before and after activation with trypsin (activated proCPB).

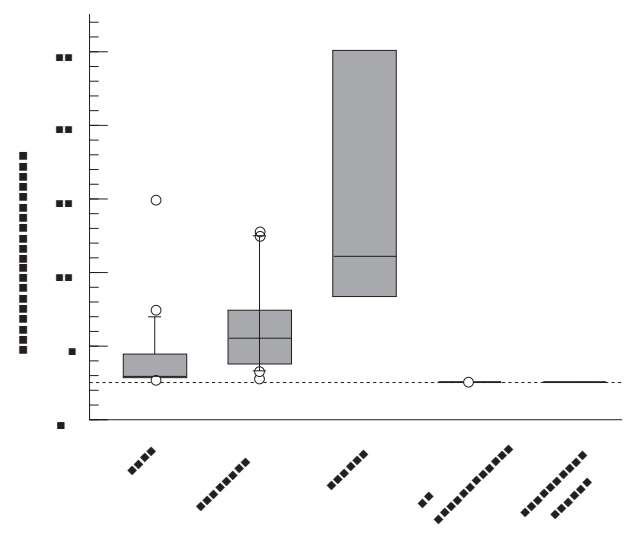

Figure 5 Immunoreactive carboxypeptidase B activation peptide (CAPAP) in serum from patients with acute pancreatitis divided up according to severity of attack. Samples from patients with acute abdominal pain for known reasons other than acute pancreatitis (no pancreatitis) and from patients with newly diagnosed pancreatic cancer are also shown.

dilution curves of pure proCPB before and after activation with trypsin. Levels of irCAPAP down to around $0.15 \mathrm{nmol}$ could be detected. The dilution curves for CAPAP (standard) and proCPB were not parallel. After trypsin activation, the curves became parallel and the immunoreactivity of proCPB increased by a factor of around 10 .

Table 2 Median (range) concentrations of the immunoreactive activation peptide of carboxypeptidase $B$ (irCAPAP) in urine and serum and serum pancreatic amylase

\begin{tabular}{|c|c|c|c|}
\hline \multirow[b]{2}{*}{ Diagnosis } & \multicolumn{2}{|l|}{ irCAPAP (nmol/l) } & \multirow[b]{2}{*}{ Amylase ( $\mu$ kat/l) } \\
\hline & Urine & Serum & \\
\hline \multicolumn{4}{|l|}{ Acute pancreatitis } \\
\hline Mild & $0.600(0-80.5)$ & $1.000(0.4-25.0)$ & $31.0(5.2-160)$ \\
\hline Moderate & $30.0 \quad(0.6-400.0)$ & $6.1 \quad(0.7-20.8)$ & $40.0(14-180)$ \\
\hline Severe & $220.0 \quad(150.0-300.0)$ & $(9.3-70.0)$ & $89.0(22.0-198.0)$ \\
\hline Non-acute pancreatitis & $0.000(0.0-1.5)$ & $0.000(0.0-0.0)$ & - \\
\hline Pancreatic cancer & $0.000(0.0-0.0)$ & $0.000(0.0-0.0)$ & - \\
\hline
\end{tabular}

Table 3 Correlation between severity and concentrations of the immunoreactive activation peptide of carboxypeptidase $B$ (irCAPAP) in urine and serum

\begin{tabular}{llll}
\hline \multirow{3}{*}{ Groups compared } & \multicolumn{2}{l}{ irCAPAP } & \\
\cline { 2 - 3 } & Urine & Serum & Amylase \\
\hline Severe $v$ moderate & 0.0197 & 0.0250 & 0.7538 \\
Severe $v$ (moderate + mild) & 0.0038 & 0.0088 & 0.4169 \\
Moderated $v$ mild & 0.0001 & 0.0055 & 0.1405 \\
\hline
\end{tabular}

The $\mathrm{p}$ values shown were obtained by using the Mann-Whitney $\mathrm{U}$ test. Corresponding values for pancreatic amylase in serum are also shown.

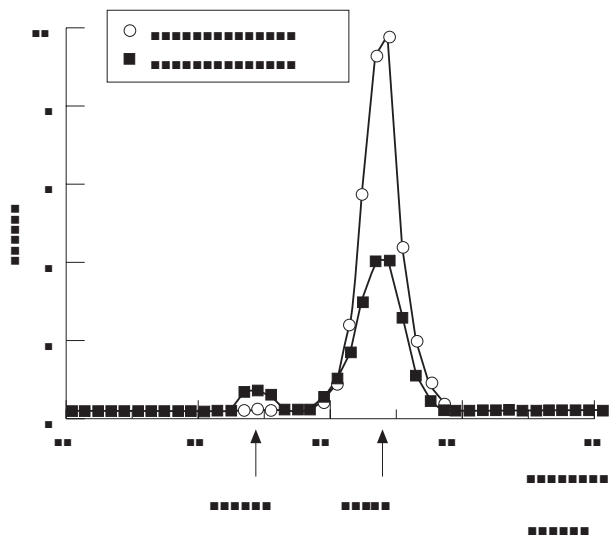

Figure 6 Characterisation of carboxypeptidase $B$ activation peptide (CAPAP)-like immunoreactivity by gel filtration (Sephadex G-50 column) of serum and urine samples from a patient with acute pancreatitis.

irCAPAP IN SERUM

In serum from patients with acute pancreatitis, irCAPAP levels were increased up to $70 \mathrm{nmol} / \mathrm{l}$. Serum samples from patients with severe attacks showed large amounts of irCAPAP, median $17.1 \mathrm{nmol} / 1$ (range 9.3-70 $\mathrm{nmol} / \mathrm{l}$ ). The moderate cases showed lower values, median $6.1 \mathrm{nmol} / 1$ (range $0.7-20.8 \mathrm{nmol} / \mathrm{l}$ ). In the mild cases, the median level was $1.0 \mathrm{nmol} / 1$ (range $0.4-25.0 \mathrm{nmol} / \mathrm{l}$ ). Figure 5 and table 2 show the correlation of irCAPAP in serum with severity, and table 3 gives the statistical analysis.

Tables 2 and 3 also give the correlation with severity for pancreatic amylase in serum for comparison.

Characterisation by gel filtration of the immunoreactivity in serum from patients with acute pancreatitis shows that most immunoreactive material is eluted in a volume similar to the molecular size of the activation peptide (CAPAP) and to a smaller extent in a higher molecular mass volume corresponding to proCPB (fig 6).

\section{irCAPAP IN URINE}

Urine samples from patients with severe acute pancreatitis contained large amounts of irCAPAP, median $220 \mathrm{nmol} / 1$ (range 150-300 $\mathrm{nmol} / \mathrm{l}$ ). irCAPAP was also found in urine from patients with mild and moderate attacks, although in lower concentrations. In moderate pancreatitis, the median level was $30.0 \mathrm{nmol} / 1$ (range $0.6-400 \mathrm{nmol} / \mathrm{l}$ ) and in mild cases 0.6 $\mathrm{nmol} / \mathrm{l}$ (range $0-80.5 \mathrm{nmol} / \mathrm{l}$ ). Figure 7 and table 2 show the correlation between urine levels of irCAPAP and severity, and table 3 gives the statistical analysis. Tables 2 and 3 also give the correlation with severity for pancreatic amylase in serum for comparison.

Characterisation by gel filtration of the immunoreactivity in urine from patients with pancreatitis showed only one immunoreactive peak equivalent to the molecular size of CAPAP and no measurable proCPB (fig 6). Characterisation by preparative gel electrophoresis of the CAPAP-like immunoreactivity in urine from patients with acute pancreatitis 


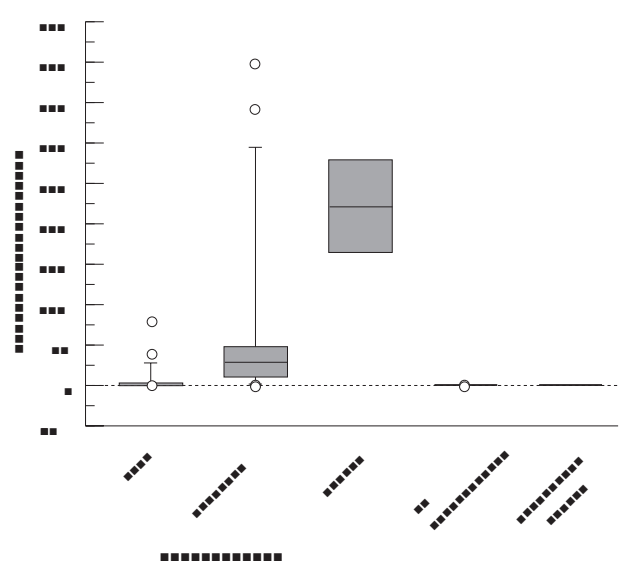

Figure 7 Immunoreactive carboxypeptidase $B$ activation peptide (CAPAP) in urine from patients with acute pancreatitis divided up according to severity of attack. Samples from patients with acute abdominal pain for known reasons other than acute pancreatitis (no pancreatitis) and from patients with newly diagnosed pancreatic cancer are also shown.

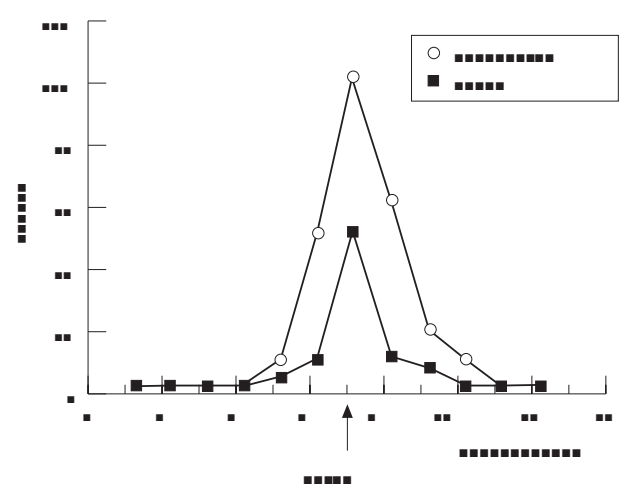

Figure 8 Characterisation of immunoreactive carboxypeptidase $B$ activation peptide (CAPAP), in urine from a patient with acute pancreatitis, by preparative gel electrophoresis. Application slit at zero. Anode to the right.

showed that this immunoreactivity had the same electrophoretic mobility as pure CAPAP (fig 8).

Serum and urine from patients with pancreatic cancer contained no irCAPAP, and serum and urine from 34 patients with acute abdominal pain that was not due to pancreatitis all contained no or low $(<1.5 \mathrm{nmol} / \mathrm{l})$ levels of irCAPAP.

STABILITY OF irCAPAP IN SERUM AND URINE There was no decline in the levels of irCAPAP during storage for up to 4 weeks at $+4^{\circ} \mathrm{C}$ in serum or urine from patients with acute pancreatitis.

\section{Discussion}

The activation mechanism for porcine proCPB is known in detail. ${ }^{4}$ The reaction starts with the tryptic release of an $\mathrm{N}$-terminal 95 amino acid peptide, CAPAP(1-95). This peptide is then further degraded at the C-terminus by the action of active CPB and further by trypsin to an 81 amino acid peptide, $\operatorname{CAPAP}(1-81)$. The theoretical molecular size of the human activation peptide postulated from earlier cDNA studies of human proCPB is $9399.4 \mathrm{Da} .{ }^{13}$ The mass spectroscopic analysis shows an almost identical size for the purified human CAPAP with an $\mathrm{N}$-terminus identical with that deduced from cDNA analysis. This shows that we are dealing with the CAPAP $(1-81)$ activation peptide also in man and indicates that the mechanism of activation of human proCPB is similar to that of the porcine system.

The antibodies against CAPAP obtained in this study show some cross reaction with the proenzyme; this is understandable since the activation peptide makes up about $25 \%$ of the proenzyme. This makes it difficult to quantify the true level of irCAPAP in serum with the present assay. More specific antibodies for CAPAP can probably be obtained by immunising with the synthetic C-terminus of this peptide using a similar method to that used for TAP, prophospholipase, ${ }^{12}$ and enterostatin. ${ }^{14}$ By analysing urine samples, however, the cross reaction with the procarboxypeptidase is overcome since the proenzyme does not appear in the urine.

This study shows that the level of irCAPAP in urine and serum obtained early during the disease correlates with the severity. This is a very important finding for two reasons. Firstly, it shows that measuring irCAPAP in urine or serum may be a very valuable single diagnostic tool clinically, both in the diagnosis of acute pancreatitis and in the estimation of the severity of the attack. Secondly, it shows that this trypsin induced process does occur early during acute pancreatitis. The correlation with severity is a finding that favours the hypothesis that unbalanced tryptic activity in the pancreatic gland due to trypsin-protease inhibitor imbalance is "the motor" of the inflammatory process in acute pancreatitis. ${ }^{15}$ It is not until this imbalance occurs that trypsin can activate the cascade systems and the other pancreatic proenzymes including proCPB. Activation of trypsinogen to trypsin can probably occur without this imbalance, but as long as there are inhibitors present, there is no activation of the other proenzymes and the inflammatory cascade systems, and there is no inflammation. Thus the appearance of irCAPAP in the urine signals uncontrolled trypsinogen activation within the pancreas. irTAP, however, can theoretically occur in urine in situations where trypsinogen activation is still balanced by protease inhibitors.

TAP has not been determined in blood samples from patients with acute pancreatitis to our knowledge. This may be because, owing to its small size, it is eliminated very quickly from the circulatory system. Another advantage to the measurement of CAPAP is the stability of this peptide in serum and urine. Smaller peptides like TAP and enterostatin are unstable, and the samples have to be boiled immediately to prevent degradation.

Classification of severity in clinical material of acute pancreatitis is a problem, especially when the classification is performed retrospectively as in this case. In our patient material all four patients with severe pancreatitis had high concentrations of irCAPAP in both the urine and the serum. However, in the group of patients with moderate pancreatitis, another 
two patients had high concentrations of irCAPAP. These two patients did not fulfil our simplified clinical criteria for severe pancreatitis. However, both of these cases were severe according to Ranson, with a score of at least 4 and 6 respectively.

Another important factor is the timing of the sampling in relation to the onset of the disease. The release of activation peptides probably occurs very early in the pathophysiology of the disease, and samples obtained on the second or third day after onset may already show declining levels. This will need to be studied further.

As for the specificity of the CAPAP assay for the diagnosis of acute pancreatitis, further clinical studies are needed to determine whether irCAPAP can appear in the urine in other situations particularly in other acute abdominal disorders - for example, perforated ulcers. Our experience with an assay for trypsin in complex with $\alpha 1$-protease inhibitor shows that in some situations small proteins can be absorbed from the intestine and appear in the circulation. ${ }^{16}$ Thus the normal turnover of CAPAP in the intestine and in the circulation needs to be studied.

In conclusion, measurement of CAPAP in urine and perhaps also in serum may in the future be a superior laboratory tool for the diagnosis of acute pancreatitis, as it combines high specificity for the diagnosis with an accurate estimate of severity in a single test performed on admission.

This study was supported by grants from the Swedish Medica Research Council projects no 17X-8305-09A and the FoundaResearch Council projects no $17 \mathrm{X}-8305-09 \mathrm{~A}$ and the Four
tions for Research at the University Hospitals in Malmö.

1 Gudgeon M, Heath DI, Hurley P, Jehanli A, Patel G, Wilson $\mathrm{C}$, et al. Trypsinogen activation peptides assay in the early severity prediction of acute pancreatitis. Lancet 1990;335:4-8.

2 Gudgeon AM, Patel G, Herman-Taylor J, Hurley P, Bowyer RC, Jehanli AM. Detection of human pancreatic prophospholipase A2 activation using an immunoassay for the free activation peptide DSGISPR. Ann Clin Biochem 1991; 5:497-503.

3 Håkansson H-O, Borgström A, Ohlsson K. Human cationic pancreatic elastase in acute pancreatitis. Scand 7 Clin Lab Invest 1993;53:17-24.

4 Burgos FJ, Salva M, Villegas V, Soriano F, Mendez E, Avilés F. Analysis of the activation process of porcine procarboxypeptidase B and determination of the sequence of its activation segment. Biochemistry 1991;30:4082-9.

5 Yamamoto KK, Pousette Å, Chow P, Wilson H, El Shami S, French CK. Isolation of a cDNA encoding a human serum marker for acute pancreatitis. F Biol Chem 1992;267:257581.

6 Kimland M, Russick C, Marks WH, Borgström A. Immunoreactive anionic and cationic trypsin in human serum. Clin Chim Acta 1989;184:31-46.

7 Folk JE, Piez KA, Carroll WR, Gladner JA. Carboxypeptidase B. Purification and characterisation of the porcine enzyme. F Biol Chem 1960;235:2272-7.

8 Johansson BG. Agarose gel electrophoresis. Scand f Clin Lab Invest 1972;124(suppl):7-19.

9 Lowry OH, Rosebrough NJ, Farr AL, Randall RJ. Protein measurement with a Folin phenol reagent. F Biol Chem 1951;193:265-75.

10 Thim L, Hansen MT, Sorensen AR. Secretion of human insulin by a transformed yeast cell. FEBS Lett 1987;212: 307-12.

11 Thim L, Woldike HF, Nielsen PF, Christensen M, Lynch-Devaney K, Podolsky DK. Characterisation of human and rat intestinal trefoil factor produced in yeast. Biochemistry 1995;34:4757-64.

12 Bolton AE, Hunter WM. The labelling of proteins to high specific radioactivities by conjugation to a ${ }^{125}$ I-containing acylating agent. Biochem $\mathcal{F}$ 1973;133:529-39.

13 Yamamoto KK, Pousette Å, Chow P, Wilson H, Shami SE, French C. Isolation of a cDNA encoding a human serum marker for acute pancreatitis. F Biol Chem 1992;267:257581.

14 Bowyer RC, Jehanli AMT, Patel G, Hermon-Taylor J. Development of enzyme linked immunosorbent assay for free human procolipase activation peptide (APGPR). Clin Chim Acta 1991;200:137-52.

15 Ohlsson K, Balldin G, Bohe M, Borgström A, Genell S, Lasson Å. Pancreatic proteases and antiproteases in pancreatic disease; biochemical, pathophysiological and clinical aspects. Int $\mathcal{F}$ Pancreatol 1988;3:67-78.

16 Borgström A, Lasson Å, Ohlsson K. Patterns of immunoreactive trypsin in serum from patients with acute abdominal disorders. Scand $\mathcal{F}$ Clin Lab Invest 1989;49:757-6. 